\title{
SEEKING THE FACE OF INNOVATION WITH THE ETHICAL COMPASS OF EMMANUEL LÉVINAS
}

\author{
Gabriel J. Costello \\ Galway-Mayo Institute of Technology and \\ Centre for Innovation and Structural Change \\ National University of Ireland \\ Galway, Ireland \\ Brian Donnellan \\ Business Information Systems Group \\ National University of Ireland \\ Galway, Ireland
}

\begin{abstract}
A recent biographer has described the philosophy of Emmanuel Lévinas as being permeated by one simple but profound theme: Western philosophy has at best ignored and at worst suppressed the "Other." The approach of this study involved a concept-centric examination of innovation terminology assembled from key papers in the area. The analysis presents evidence of the lack of regard in the literature for the human dimension, with the notable exception of the work of Andrew Van de Ven and his collaborators. Consequently, an ethical definition of innovation is proposed inspired by the theoretical lens of Lévinas. We argue that the work makes a practical and philosophical contribution to the emerging debate on ethics by the Information Systems community. Furthermore, we suggest that our analysis has implications for diffusion of innovations research increasingly being carried out in an open-innovation paradigm.
\end{abstract}

Keywords Emmanuel Lévinas, ethics, phenomenology, Claudio Ciborra, Andrew Van de Ven

Please use the following format when citing this chapter:

Costello, G. J., and Donnellan, B., 2008, in IFIP International Federation for Information Processing, Volume 287, Open IT-Based Innovation: Moving Towards Cooperative IT Transfer and Knowledge Diffusion, eds. León, G., Bernardos, A., Casar, J., Kautz, K., and DeGross, J. (Boston: Springer), pp. 97-117. 


\section{INTRODUCTION}

Davis (1996, p. 1) has described the philosophy of Emmanuel Lévinas as being permeated by one simple but profound theme: "Western Philosophy has consistently practiced a suppression of the Other." The principal objective of this paper is to examine the face of innovation - extracted from definitions of the phenomenon in seminal papers - through the lens of the ethical philosophy of Lévinas. Furthermore, the study aims to continue the debate proposed by Claudio Ciborra that the position of information and communications technology (ICT) in organizations requires a shift from the present focus on the scientific paradigm to an alternative center of gravity: human existence in everyday life. Such a shift, we argue must take us to the world of philosophy (Downie 2005) and in particular to one of its first questions broadly framed by Socrates: How should I live? The study addresses the implications of Lévinas's theoretical lens for two areas: our understanding of the term innovation and the consequences of open IT-based innovation for diffusion of innovations (DOI) research. The approach consists of examining innovation terminology through a concept analysis of over 30 definitions (Webster and Watson 2002); assembled from key papers and guided by the vision of Lévinas. The analysis indicates that only the work of Van de Ven and his colleagues (Van de Ven et al. 2000) addresses the major contemporary ethical issues facing the information systems community: the human dimension and the use of resources. In addition, the paper argues that the work of Lévinas can save Ciborra's Copernican revolution from the quagmire of solipsism. The work is important in the context of the current priority being given to the debate on ethics by the Information Systems community. The paper is organized as follows. First, the development of the philosophy of Lévinas is presented in the context of his engagement with the phenomenology of Edmund Husserl and Martin Heidegger. Then the influence of phenomenology on contemporary information systems research is presented, chiefly through the work of Claudio Ciborra. Following this, a brief overview of the literature on innovation and information systems is outlined and an analysis of innovation definitions is presented in the form of a concept matrix. Resulting from this, a definition of innovation is proposed based on the Lévinasian éthique. Finally the implications for innovation studies are discussed and future work is proposed in the concluding section.

\section{BACKGROUND}

Recently, views within the information systems literature express the need for researchers to have a firm philosophical basis for their work. For example, Weber (2003) contends that there is a requirement to improve theory-building skills and in doing so researchers must "reflect deeply on and understand the ontological and epistemological assumptions" (p. v) and be true to their philosophical position. Such a philosophical program, we argue, must involve what Quinton (2005, p. 702) describes as a rationally critical and systematic thinking on the "conduct of life (ethics or the theory of value)." This section will trace the philosophical antecedents of the work of Lévinas to the phenomenological program of Edmund Husserl and then consider the influence of phenomenology on the IS debate. 


\subsection{The Phenomenology of Edmund Husserl}

Edmund Husserl, the founding father of Phenomenology, is regarded as having start instigated one of the most important philosophical movements of the $20^{\text {th }}$ century (Grossmann 2005). The system has had an immense influence in Europe in areas spanning psychology, law, values, aesthetics, and religion (Inwood 2005a). He considered that philosophy should be carried out as a rigorous science using the structured methodology of reason and his vision was that the phenomenological approach (of bracketing the natural world and a reduction to pure consciousness) could overcome and synthesize the radical disagreements of contemporary philosophy. Husserl's original studies were in the area of mathematics and his most influential teacher was the philosopher Franz Brentano. His philosophy underwent a transition from his earlier studies on the phenomenology of mathematical and logical concepts to the transcendental idealism developed in his later major work, Ideas: General Introduction to Pure Phenomenology (see "Introduction" in Elveton 1970). Lauer (1965) argues that with the passage of time a precise definition of phenomenology became more difficult but proposed that the term could be traced back to a "distinction made by Kant between phenomenon or appearance of reality in consciousness, and the noumenon, or being of reality itself" (p. 2). However, he points out that Husserl rejected what he perceived as the dualism of Kant. Lauer continues to explain the phenomenology of Husserl as both a method and a philosophy. Method in so far as it provides the steps that must be followed "to arrive at the pure phenomenon, wherein is revealed the very essence not only of appearances but also of that which appears" (p. 8). In the realm of philosophy "it claims to give necessary, essential knowledge of that which is" (p. 8). Thus phenomenology advocates a "return to things because a 'thing' is the direct object of consciousness in its purified form" (p. 9). This approach was in opposition to illusions, verbalisms, or mental constructions implied by many contemporary movements. In connection with the philosophy of the mind, Horner and Westacott (2000) explain that phenomenology attempts to describe exactly what happens when a person is conscious of something and that the approach typically is set in motion by recounting the way things truly appear to us. This is in contrast to other approaches that examine the role of brain processes in relation to consciousness or discuss the mind-brain controversy. Rather poignantly, as many of his pupils set out on very independent paths, Husserl in later years saw himself more and more as a leader without followers. Paul Ricoeur, who translated Husserl's Ideas $I$ and commented extensively on him, even stated that the "the history of phenomenology is the history of Husserlian heresies" (Moran 2000, p. 3). However such remarks must be placed in the context of a tragic period in European history during which Husserl's name was dropped from the Freiberg faculty lists in 1936 coupled with his deep personal disappointment with the direction that Martin Heidegger had taken phenomenology (Moran 2000, p. 90).

\subsection{Lévinas: Face-to-Face with the Other}

Born in Lithuania, Emmanuel Lévinas is credited with introducing phenomenology to France after his studies with Husserl and Heidegger, who were major influences on his 
work. His considerable volume of publications over a period of 60 years made him a key catalyst in the development of French $20^{\text {th }}$ century philosophy, including the emergence of the existentialism of Jean-Paul Sartre and Maurice Merleu-Ponty (Davis 1996, p. 3). His major work Totality and Infinity (1961) explored such themes as time death, and relations with others and increasingly his philosophy was concerned with marking out an ethical face-to-face with the Other: a concept that while "immediate and singular, is none the less transcendent" (Ainley 2005, p. 512). Lévinas gave phenomenology a radical ethical orientation variously described as his phenomenology of alterity (alterité) or his phenomenology of sociality that starts from the experience of "the face" (le visage) and emanates from the other's proximity. The colorful philosopher Alphonso Lingis (1998) has described the concept of face as the "central moment of all of Lévinas's phenomenology" and goes on to explain that while the theoretical structure of his work begins with an "ontological elucidation of what it mean to be existent" (p. xxix), his subsequent analysis of the intentional or transcending led him to a region "otherwise than being” (xix). This latter reference is to Lévinas' most notable later work, Otherwise than Being, or, Beyond Essence, which Moran sees in part as a response to criticism by Jacques Derrida. Lévinas's use of the term face has become the hallmark of his legacy and in his writing stands for the "real concrete presence" of another which "blossomed into a metaphor" for many aspects of the person and culture (Moran 2000, p. 347).

Bergo (2007) states that Lévinas's "phenomenological descriptions of intersubjective responsibility are built upon an analysis of living in the world" and are unique to him. However, we would argue that this is unfair to Husserl, who many years earlier in his lectures on nature and spirit had "maintained that an objective external world can only be experienced inter-subjectively (i.e., by a plurality of individual knowing subjects) who are in a position to exchange information with each other" (Posselt 2005, p. 53). Significantly, this lecture became the inspiration for Edith Stein's doctoral thesis on empathy, a topic closely related to the Other of Lévinas.

Now, we propose, it is worth examining the relationship of Lévinas with the two most influential phenomenologists of our time, Edmund Husserl and Martin Heidegger, drawing from a number of studies (Bergo 2007; Davis 1996; Lingis 1998; Moran 2000). In this regard we must admire Lévinas's timing: arriving in Freiburg in 1928, where he was able to attend the last lectures of Husserl on phenomenological psychology and intersubjectivity together with Heidegger's first seminars when he became Husserl's successor that same year. Lévinas was very appreciative of the amount of time afforded to him by Husserl but was clearly captivated by what Inwood (2005b) describes as the enthralling brilliance of Heidegger's lecturing style. During this period, Moran tells us that Lévinas sided with Heidegger's formulation of being-in-the-world against Husserl's transcendental idealism. His first publication was a review of Husserl's Ideas I where in the conclusion, he rejected "quasi-solipsistic egological reduction" (Moran 2000, p. 323 ) as a means to pursue authentic objectivity, and presented the first steps in his long journey of phenomenological intersubjectivity. This is an important point for one of the aims of our paper, namely to consider the implications of Ciborra's call for IS researchers to return to the human person, a topic we will return to later. Significantly, Lévinas's award winning thesis presented for his doctorate at the University of Strasburg in 1929 and published the following year was titled The Theory of Intuition in Husserl's Phenomenology. Both Davis and Moran describe Lévinas's reorientation from his initial use of Heidegger's phenomenology to support his critique of Husserl's subjectivism, to 
the point where Heidegger became the object of a "complete rebuttal" (Davis 1996, p. 21). Two factors seem to have come into play here. Firstly in the purely philosophical realm, where he is quoted by Davis (1996, p. 21) as concluding that the Heideggerian destruction of metaphysics enforces a major flaw in Western thought:

[T]his supremacy of the Same over the Other seems to me to be entirely maintained in the philosophy of....He does not destroy, but rather he epitomizes a whole current of Western thought....The Dasein that Heidegger puts in the place of the soul, of consciousness, of the Ego, retains the structure of the Same.

The second important factor was his realization, when alerted by Alexander Koyré, of the influence of National Socialism on Heidegger, which according to Moran horrified Lévinas and opened his eyes to Heidegger's emphasis on authenticity as in fact masking a self-centered weakness that was open to exploitation by such totalitarian ideologies.

One aspect of the work of Lévinas that also needs to be addressed is literally a matter of semantics. This facet is important for our paper, which has few references from the main literature that is associated with ethics. Lévinas did not discuss issues such as laws, rules, rights, duties, and the language or logic of ethical enquiry (Davis 1996, p. 47). He had a more ambitious program; that of developing a first philosophy or what Derrida (quoted in Bergo 2007) called writing an "ethics of ethics." Both Moran and Davis translate this word, from the French éthique, as his study of "the ethical" analogous to someone studying "the political" rather than just politics. This is also the reason why we chose compass in the title when referring to the Lévinasian ethic rather than using, for example, program.

Having at this stage introduced the work of Lévinas as it emerged from the phenomenology of Husserl and tested in the ferment of Heidegger, we will now consider implications for the information systems field chiefly in relation to the labyrinth of Claudio Ciborra.

\subsection{The Influence of Phenomenology on the Information Systems Debate}

Ciborra clearly acknowledges the influence of phenomenology, especially in his later work where he proposes that a return to its origins can provide an antidote to the Krisis he saw unfolding in the information systems field. He specifically admits his debt to Husserl's 1934 lectures on the Crisis of European Sciences and Transcendental Phenomenology and the resulting analysis that the "crisis comes about due to the separation between people and science" (Ciborra 2002, p. 15). Martin Heidegger was a major influence on Ciborra, who harnessed his ideas on technology to analyze such concepts as information infrastructure. However, it must be remembered that Heidegger's phenomenology moved significantly away from many of the positions of Husserl. It is reasonable to deduce that Ciborra's development of the idea of bricolage was influenced by the suggestion of Heidegger in his work Being and Time that "our knowledge and basic way of encountering the world are obtained through the use of, and not the scientific description of, objects" (Ciborra 2000, p. 90). 
This section has presented the work of Lévinas in the context of the antecedent development of phenomenology by Husserl and the subsequent influence of phenomenology on the contemporary information systems debate chiefly through the work of Claudio Ciborra.

\subsection{A Note on the Research Approach}

One aspect of the approach in this paper has been to follow the advice of Gian-Carlo Rota to Robert Sokolowski as he embarked on writing his book on phenomenology. Rota suggested that philosophers should follow the lead of mathematicians who are more inclined to extract and use rather than engage in complex exegesis. As a result, Sokolowski developed his book in order to offer the possibility of "philosophical thinking at a time when such thinking is seriously called into question or largely ignored"(Sokolowski $2000, \mathrm{p} 2)$. This paper is no more than a modest attempt to facilitate debate among the DOI community on an important area of philosophy. Furthermore the approach is broadly that of responding to the following questions:

- Does the philosophy of Emmanuel Lévinas affect our current understanding of innovation terminology?

- What are the resulting implications for the conduct of DOI research in an open IT-based paradigm?

Additionally, the writing style takes heed of Kerlin's (1997) lament concerning the introduction of the "deadly impersonal" third person to debates in philosophy and business ethics "under the influence of the social sciences" (p. 1432). Furthermore, he argues that the first person facilitates lively writing and avoids any "hesitation to state positions" (p 1432).

\subsection{A Brief Engagement with the Life-World (Lebenswelt) ${ }^{1}$}

The rigor versus relevance debate still resonates from 2007 European Conference on Information Systems, where precursor essays such as that of Benbasat and Zmud (1999) had not lost any of their topicality. Is not the subject of relevance particularly challenging as we struggle to engage with one of the most profound and influential philosophers of our time? Let us briefly provide a short incident from the life-world that provided one inspiration for this paper. Our research and supervision of undergraduate projects takes us to a number of MNC (multinational corporation) subsidiaries that span a wide area of industrial sectors from medical devices and software development to electro-mechanical services. During a plant tour of a subsidiary in the teeth of much local and corporate change, the manager showed notice boards where he had, with the

${ }^{1}$ Husserl, in his later work Experience and Judgement (1938), emphasized the importance of returning to the life-world (Lebenswelt), the world of our ordinary experience (Moran 2000, p. 12) 
permission of the staff, placed organization charts that contained photographs with the years of service of each person in the subsidiary. The reason, he explained, was that he wanted anyone who came to the plant, especially those deciding its future, "to see the faces of its people." This statement impressed very much and immediately brought to mind the philosophical perspective of Emmanuel Lévinas.

\section{SEEKING THE FACE OF INNOVATION}

This section will first provide a very brief flavor of some of the debates within the general management and IS literature on the subject of innovation. Following this we will examine over 30 definitions of innovation in light of our previous review of the ethical philosophy of Emmanuel Lévinas.

\subsection{Innovation and Information Systems}

The voluminous and eclectic innovation literature has been recently described as a fragmented corpus (Adams et al. 2006). In an important antecedent paper, Wolfe (1994) concluded that it had made little contribution to the understanding of innovative behavior in organizations and his evaluation of the results as being "inconclusive, inconsistent and characterized by low levels of explanation" (p. 405) was surely a pointed criticism of the field. Slappendel's (1996) subsequent mapping of the literature on innovation in organizations in terms of three theoretical regions - the individualist perspective, the structuralist perspective, and the interactive process perspective - is highly regarded and has been profitably applied by the IS community to the analysis of software process improvement innovations (Kautz and Nielsen 2004). Recently, there have been some noteworthy attempts to provide a more holistic appreciation of the innovation landscape such as the compilations by Fagerberg et al. (2005) and by Shavinina (2003). However, Fagerberg's (2005, p. 20) conclusion that "our understanding of how knowledge - and innovation - operates at the organizational level remains fragmentary" and "that further conceptual and applied research is needed" indicates a scarcity of progress in the intervening period. Moving closer to home, Avgerou (2002) comes to the surprising conclusion that "the term innovation is not actually widely used" (p. 141) in the information systems literature. Swanson (1994), who has been notable among the IS research community in addressing the subject, argues that the innovative deployment of information technology is "increasingly crucial to competitive survival and success" (p. 1069). In the context of this conference theme of open-innovation, Chesbrough's (2003, p. 12) description of innovation as a "difficult process" is in line with the sentiments of the above literature.

One of the main challenges of a review of innovation is the range of definitions from a wide body of literature. In their analysis of the terms innovation and innovativeness from 21 empirical studies in the new product development literature, Garcia et al. (2002, p. 110) discovered that "no less than fifteen constructs and at least 51 distinct scale items" were used, leading to a great deal of ambiguity. 


\subsection{Andrew Van de Van and the Minnesota Studies}

The work of Andrew Van de Van has made a significant contribution to innovation scholarship since the early 1980s. We will now give a brief overview of his work and its significance should become apparent when our analyses of the data are presented in section 3.3. This pioneering work was carried out during the Minnesota Innovation Research Program (MIRP) and its publications are generally known as the Minnesota studies (Van de Ven et al. 2000). A testimony to the enduring quality and wide-regard of these seminal studies is the fact that although the book was originally published in 1989 and subsequently taken out of print, it was reprinted in the year 2000. The MIRP program was carried out by approximately 40 researchers, now scattered among faculty across the globe, who conducted longitudinal studies of 14 innovations during the 1980s. Significantly, Van de Ven and his team "returned to the library" in the 1990s as they considered that if it took 10 years to gather the data, then they "deserved at least ten years to analyze and make sense of the data" (Van de Ven et al. 2000, p. xx). As this paper is focused on analyzing definitions of innovations, it is worth pausing and reflecting here on his definition of the phenomenon (Van de Ven 1986, p. 591).

Innovation is defined as the development and implementation of new ideas by people who over time engage in transactions with others within an institutional context. $^{2}$

As a result, four basic factors are implicit in the definition: new ideas, people, transactions, and institutional context. We will discuss the implications of Van de Ven's work, for the theme of this paper, in the remaining sections.

\subsection{Definitions of Technological Innovation: An Analysis}

In the course of his work, McInerney (2004) assembled over 30 author-centric definitions of innovation from publications since 1960. These were built, like Russian dolls, from antecedent work by Rahmanseresht (1988) and Zain (1993) with Schumpeter's (1934) earlier definition being added by the authors in recognition of its significance in innovation studies.

A content analysis of the innovation definitions was then carried out through converting the author-centric definitions in the literature into a concept-centric format in order to identify the most common concepts and also ones that may require further attention (Webster and Watson 2002). Additional dimensions were also added to the concept matrix, shown in Appendix A, to facilitate the analysis. The concepts are categorized into whether they are an adjective (for example new, radical), a noun (for example product, market), or a verb (for example implementation, adoption), and numbered 16, 33, and 18 respectively. Another objective was to enable a meta-analysis of the table in order to investigate if the definitions can contribute to the development of

${ }^{2}$ We have added the italics as in the context of this paper, the use of the term others takes on added significance. 
theory, for example whether they exhibit parsimony or have any theoretical glue (Whetten 1989). The rows provide the paper references from which the concepts were extracted and their occurrence. The sorting order from left to right was not done alphabetically in order to try to indicate chronologically when the concept appeared in the literature. The frequency of use of a particular concept in the definitions is indicated from the number of asterisks in the table columns. For example, while product and process were used by Schumpeter and many others early on, the idea of "know-how" was introduced by Freeman in 1982. No effort has been made at this stage to apply any frugality to an evidently un-parsimonious table using, for example synonyms, as it was decided just to use the raw data for this study.

The important result of this analysis, we believe, is that there are only two references to people (or our Other in this study) and one reference to resources, densely crowded into the table in Appendix A, but which can be further examined using the wonders of a word processing "zoom" button — or a magnifying glass! This, we believe, is extremely important as it covers the two major areas of ethics: the role of people and resources in the development and implementation of an innovation. Furthermore, the former and latter are tied together within such debates as that of justice. Surely the other significant feature is that these two definitions both emanate from the work of Andrew Van de Ven and his colleagues in the 1980s. There are many other analyses that we believe can be extracted from this table, but our basic focus here is the search for a human "element" in the innovation literature through examination of important definitions. However, even a cursory look at the cluster of the asterisks and comparing them with Schumpeter's original definition would lead to a suspicion: la plus ça change, la plus c'est la même chose.

\section{DISUSSION}

We have now worked our way through the origins of phenomenology to the ethic of Lévinas and then applied our gleanings to the world of innovation studies. Previously the ethical concept of the Other has been applied to the role of innovation in literary studies (Attridge 1999) while this work relates it to technological innovation. Based on our analysis, we will first propose a novel definition of innovation and then consider its practical implications for DOI research in the era of open IT-based innovation.

\subsection{An Ethical Definition of Innovation}

The table of innovation definitions in Appendix B contains an array of concepts that, for the most part, do not take into account the human aspect of the phenomenon. Therefore, we believe it is incumbent on us to attempt to stimulate some debate by offering a starting point. We have chosen to do this by taking one highly regarded definition, that of Zaltman et al. (1973), sprinkling it with the scholarship of Van de Ven, and adding Ciborra's human focus in order to propose a Lévinasian inspired definition. Those who are interested and unimpressed but would like to join this nascent open source community are invited to examine the database of definitions in the appendix — distilled from over 30 years of scholarly endeavor. 
Proposition: An innovation is a human activity resulting in an artifact, idea, practice, organization, learning, or information system - perceived to be new by the unit of adoption - that is cognizant of the Lévinasian Other. Consequently, ethical issues must be considered that affect initiating, implementing, and using the innovation together with the associated employment of resources.

We will now discuss implications of this new conceptualization for DOI research, the open innovation paradigm and the legacy of Claudio Ciborra.

\subsection{Implications for DOI Research in the Context of Open IT Innovation}

The novel innovation definition described in the previous section will now be examined using the following themes from the ethical and DOI literature: consequences of the diffusion of innovations and responsibility vis-à-vis an innovation.

Rogers' (2003) magnum opus does not deal with the topic of ethics per se but the section on consequences specifically raises questions of a profound ethical nature, which the following quotations illustrate (p. 440):

Instead of asking, as much past diffusion research has done- - "What variables are related to innovativeness?"-future investigations need to ask, "What are the effects of adopting innovations?"

Most past diffusion research stopped with an analysis of the decision to adopt a new idea, ignoring how this choice is to be implemented and with what consequences.

In his summary of the chapter devoted to consequences of innovation, Rogers defines two important goals of diffusion programs: raising the level of good in a system and fairness in the distribution of the good. Such concepts such as the common good and justice fall under the traditional philosophical taxonomy of the theory of value (or ethics). Furthermore, consequentialism is controversial ethical philosophy in its own right (Hooker 2005) and because of its importance in Rogers' innovation development process invites further reflection outside of this study.

Responsibility is an important concept in the study of moral and ethical philosophy (Klein 2005). We will now deal with the issue of responsibility by referring to Kerlin's (1997) joust with Peter French on the metaphysical and practical implications of the latter's work on corporate ethics. Kerlin brings French to task for treating a corporation as a "moral agent in its own right" since "we cannot reason with the organisation or shame it" and we are unable to attribute responsibility to an abstraction. He furthermore emphasizes that "our moral discourse is with the creators of the structures" (p. 1437).

Chesbrough's (2003) seminal publication on open innovation and its recent academic offspring (Chesbrough 2006) does not deal with the issue of ethics directly. However, we argue that the distributed nature of this new paradigm driven largely by advances in ICT adds additional urgency to tackling the issues of consequences and responsibility 
discussed above. The loosening of ties implicit in such cloudy conceptualizations as value constellations (Vanhaverbeke and Cloodt 2006) reinforces the dangers of Kerlin's Wizard-of-Oz syndrome where it becomes increasingly difficult to attribute responsibility to the composite innovation and its consequences. Interestingly, almost 15 years before Chesbrough's publication, the Minnesota Studies were examining network relationships using the concept of transactions. In its only indexed entry on ethics, it argued that the notion of trust among parties was a critical ethical element in the design of "transaction structures" (Ring and Van de Ven 2000). In this section of our paper, we have argued that the ethical concepts of consequences and responsibility have practical implications for the DOI research in the context of the open IT paradigm. We will now present the case that the Lévinasian theoretical lens has philosophical implications for research in this area and the wider IS landscape.

\subsection{Implications for Ciborra's Copernican Revolution}

One of Ciborra's enduring themes is his call to "go to the origins of phenomenology." According to Resca (2006), "the adoption of phenomenological philosophy represents a significant point of transition in Ciborra's work" and Ciborra (2002, p. 170) states this clearly in his chapter on Kairos (and Affectio):

We can find shelter by going to the origins of phenomenology, the philosophical line of thought that in the last century celebrated the notion of situatedness.

Ciborra argued that the position of ICT in organizations requires a shift from the present focus on the scientific paradigm to an alternative center of gravity: human existence in everyday life. Furthermore he described this realignment in terms of a Copernican revolution in the way organizations introduce and use ICT. He writes passionately about "How to get closer to practice, then, and the real life of systems in use in a fresher way?" (2002, p. 6). He proposes a new emphasis on activities such as improvisation and bricolage as part of his concern for "human existence as a neglected factor in the implementation of complex systems and organizations" (2002, p. 8). In the final lines of his "Invitation" (2002, p. 9), he continues the grand theme of a Copernican revolution by stating "I want to contribute to a transition of the field towards an Age of the Baroque in the development and management of technology in organisation and society."

While this paper has more modest objectives, we argue that our approach of engaging with the issue of ethics in information systems continues the broad aim of Ciborra's legacy and the current IS debate on ethics. However, one problem we believe is embedded in Ciborra's revolution: the danger of a return to solipsism a "view that only oneself exists" (Squires 2005, p. 883). The counteraction of this embedded tendency became the whole raison d'être of the lifework of Lévinas. The message, we argue, from Emmanuel Lévinas is that there is "someone else out there" and innovators and the information systems community must recognize their face and engage with it. However, one question remains that makes us uneasy: Is the Lévinasian Other overly sentimental, presenting us with an untenable perfection? No, we believe Lévinas himself answers this in his poetic style: 
Autonomy, the philosophy which aims to ensure the freedom, or the identity, of beings, presupposes that freedom itself is sure of its right, is justified without recourse to anything further, is complacent in itself, like Narcissus. When, in the philosophical life that realizes this freedom, there arises a term foreign to the philosophical life, other - the land that supports us and disappoints our efforts, the sky that elevates us and ignores us, the forces of nature that aid us and kill us, things that encumber us or serve us, men who love us or enslave us - it becomes an obstacle; it has to be surmounted and integrated into this life (1998b, p. 49).

\subsection{Suggestion for Future Work and Limitations of the Study}

We have endeavored to firmly root the paper within the general theme of the ethics of innovation. Consequently, we believe that there are a number of areas that require exploring in order to address the practical and philosophical implications for DOI research in an open-innovation era. In the area of practice, section 4.2 argued that research into the concept of consequences has been called for by Rogers and this is salient to the ethical debate. Also, the important question of who assumes responsibility for a technical innovation fashioned in the new open-world requires further debate.

In the area of philosophy, Lévinas's assessment of Heidegger can provide a basis for further stimulating debates given the latter's current influence on our field and on philosophical debates in general. We also propose that engaging with Lévinas with his ethical emphasis on the "face of the human other" furthers the exploration of the work of Husserl and has particular resonance with the examination of empathy by his pupil Edith Stein (1989). The importance of empathy in research has been stressed by Susman and Evered (1978), while Leonard (1998) has proposed the importance of empathic design. Additionally, McNerney's (2001) thesis described Lévinas's influence on the development of Karol Wojtyla's philosophy of participation - a major theme of Kelly's (2005) award-winning paper that we believe invites deeper study.

Furthermore we suggest that our analysis can provide the groundwork for a rediscovery and a philosophical revaluation of the contribution of Andrew Van de Ven to innovation studies.

This paper is limited by the lack of assessment of the broader ethical literature vis-àvis the information systems discipline. The analysis of the innovation definitions, while parsing the significant words, did sacrifice some rich meanings, for example those embedded in Nonaka (1990). Also, future work is required to further refine the matrix analysis, rationalize the constructs, expand the range of definitions, and extract those with an information systems focus to assist the field.

\section{CONCLUSIONS}

It is now almost 10 years since Larsen, in his assessment of IS innovation and diffusion research, declared that the "human actor as the basis unit for investigation has simply not gotten the level of attention it needs" (1998, p. 414). The aim of this paper 
has been to address this perennial issue by exploring the human aspects of innovation studies through the ethical lens of Emmanuel Lévinas and in particular his phenomenology of the Other. The approach involved the examination of over 30 definitions of innovation that were organized into a concept matrix from key papers in the area. The analysis concluded that the human person (the Other of innovation) has been ignored in the scholarly terminology with the notable exception of the work of Andrew Van de Ven, a finding that supports the hypothesis that the thesis of Lévinas holds in the reference frame of innovation studies. As a result, an ethical definition of innovation was proposed in order to invite further reflection by the IS community on an ancient philosophical question: How do we live? Added to this is a very modern philosophical question prompted by Angle and Van de Ven (1989): How do we ethically use our resources in the activity of innovation? In the discussion section, the paper argued that ethical questions are implicit in Rogers' work and the advent of the open IT paradigm adds urgency to furthering debate on these topics. We then placed our work in the context of the call by Claudio Ciborra that the position of ICT in organizations requires a shift from the present focus on the scientific paradigm to an alternative center of gravity: human existence in everyday life. However, the paper contended that the work of Lévinas can save Ciborra's Copernican revolution from a return to the predicament of solipsism which continues, wittingly or unwittingly, the suppression of the Other. Future work was suggested for a more comprehensive analysis of the innovation concept matrix and also to examine the implications of Lévinas's éthique - together with the work of other philosophers of his genre-for the development of information systems research. Finally, we suggest that our analysis can provide the groundwork for a rediscovery and a philosophical revaluation of the contribution of Andrew Van de Ven to innovation studies. Above all, we must agree with Larsen (1998, p. 411) that these are still "exciting research questions that need our attention."

\section{Acknowledgments}

The authors are grateful to the anonymous reviewers for their very helpful comments on an earlier version of this paper.

\section{References}

Adams, R., Bessant, J., and Phelps, R. 2006. "Innovation Management Measurement: A Review," International Journal of Management Reviews (8:1), pp. 21-47.

Ainley, A. 2005. "Lévinas, Emmanuel," in The Oxford Companion to Philosophy, T. Honderich (ed.), Oxford, UK: Oxford University Press, pp. 512-513.

Angle, H. L., and Van de Ven, A. H. 1989. "Suggestions for Managing the Innovation Journey," in Research on the Management of Innovation: The Minnesota Studies, A. H. Van d Ven, H. L. Angle, and M. S. Poole (eds.), New York: Harper and Row, pp. 590-607.

Attridge, D. 1999. "Innovation, Literature, Ethics: Relating to the Other," Publications of the Modern Language Association (114:1), Special Topic: Ethics and Literary Study (January 1999), pp. 20-31.

Avgerou, C. 2002. "New Socio-Technical Perspectives of IS Innovation in Organizations," in ICT Innovation: Economic and Organizational Perspectives, C. Avgerou and R. Larovere (eds.), Cheltenham, UK: Edward Elgar, pp. 141-161. 
Becker, S. W., and Whisler, T. L. 1967. "The Innovative Organization: A Selective View of Current Theory and Research" The Journal of Business (40:4), pp. 462-469.

Benbasat, I., and Zmud, R. W. 1999. "Empirical Research in Information Systems: The Practice of Relevance," MIS Quarterly (23:1), pp. 3-16.

Bergo, B. 2007. "Emmanuel Lévinas," in The Stanford Encyclopedia of Philosophy E. N. Zalta (ed.) (http://plato.stanford.edu/archives/spr2007/entries/levinas/).

Burgelman, R. A., Maidique, M. A., and Wheelwright., S. C. 1996. Strategic Management of Technology and Ennovation ( $2^{\text {nd }}$ ed.), Chicago: Irwin.

Chesbrough, H. W. 2003. "Open Innovation: The New Imperative for Creating and Profiting from Technology, Boston: Harvard Business School.

Chesbrough, H. W. 2006. "Open Innovation: A New Paradigm for Understanding Industrial Innovation," in Open Innovation: Researching a New Paradigm, H. Chesbrough, W. Vanhaverbeke, and J. West (eds.), Oxford, UK: Oxford University Press, 1-24.

Ciborra, C. 2000. "A Critical Review of the Literature on the Management of the Corporate Information Infrastructure," in From Control to Drift: The Dynamics of Corporate Information Infrastructures, C. U. Ciborra (ed.), Oxford, UK: Oxford University Press, pp. 15-40.

Ciborra, C. 2002. The Labyrinths of Information: Challenging the Wisdom of Systems, Oxford, UK: Oxford University Press.

Davies, M. 1988. The Management of Technological Innovation in Small and Medium Sized Firms in Cyprus, unpublished Ph.D. thesis, Department of Management Studies, Brunel University.

Davis, C. 1996. Lévinas: An Introduction, Cambridge, UK: Polity Press.

Derrida, J. 1980. "Violence and Metaphysics," in Writing and Difference (trans. A. Bass), Chicago: University of Illinois Press, pp. 79-153.

Downie, R. S. 2005. "Ethics and Morality," in The Oxford Companion to Philosophy, T. Honderich (ed.), Oxford, UK: Oxford University Press, p. 271.

Downs Jr., G. W., and Mohr, L. B. 1976. "Conceptual Issues in the Study of Innovation," Administrative Science Quarterly (21:4), pp. 700-714.

Drucker, P. 1985. Innovation and Entrepreneurship: Practice and Principles, London: Heinemann.

DTI. 1994. "Innovation Definition," Department of Trade and Industry, London, UK.

Elam, M. 1993. Innovation as the Craft of Combination: Perspectives on Technology and Economy in the Spirit of Schumpeter, Ph.D. Thesis, Linköping Studies in Arts and Science No. 95.

Elveton, R. O. (ed./trans.). 1970. The Phenomenology of Husserl: Selected Critical Readings, Chicago: Quadrangle Books.

Evan, W. M., and Black, G. 1967. "Innovation in Business Organizations: Some Factors Associated with Success or Failure of Staff Proposals," The Journal of Business (40:4), pp. 519-530.

Fagerberg, J. 2005. "Innovation: A Guide to the Literature," in The Oxford Handbook of Innovation, J. Fagerberg, D. Mowery, and R. R. Nelson (eds.), Oxford, UK: Oxford University Press, pp. 1-26.

Fagerberg, J., Mowery, D., and Nelson, R. R. (eds.). 2005. The Oxford Handbook of Innovation, Oxford, UK: Oxford University Press.

Freeman, C. 1982. The Economics of Industrial Innovation ( $2^{\text {nd }}$ ed.), London: Frances Pinter.

Garcia, R., and Calantone, R. 2002. "A Critical Look at Technological Innovation Typology and Innovativeness Terminology: A Literature Review," Journal of Product Innovation Management (19:2), pp. 110-132.

Gardiner, P., and Rothwell, R. 1985. "Tough Customers: Good Designs," Design Studies (6:1), pp. 7-17. 
Grossmann, R. 2005. "Phenomenology," in The Oxford Companion to Philosophy, T. Honderich (ed.), Oxford, UK: Oxford University Press, pp. 695-697.

Hooker, B. 2005. "Consequentialism," in The Oxford Companion to Philosophy, T. Honderich (ed.), Oxford, UK: Oxford University Press, pp. 162-165.

Horner, C., and Westacott, E. 2000. Thinking through Philosophy: An Introduction, Cambridge, UK: Cambridge University Press.

Hyvärinen, L. 1990. "Innovativeness and its Indicators in Small- and Medium-Sized Industrial Enterprises," International Small Business Journal (9:1), pp. 64-79.

Inwood, M. J. 2005a. "Husserl, Edmund," in The Oxford Companion to Philosophy, T. Honderich (ed.), Oxford, UK: Oxford University Press, pp. 408-410

Inwood, M. J. 2005b. "Heidegger, Martin," in The Oxford Companion to Philosophy, T. Honderich (ed.), Oxford, UK: Oxford University Press, pp. 371-375.

Kautz, K., and Nielsen, P. A. 2004. "Understanding the Implementation of Software Process Improvement Innovations in Software Organisations," Information Systems Journal (14:1), pp. 3-22

Kelly, S. 2005. "New Frontiers in the Theorization of ICT-Mediated Interaction: Exploring the Implications of a Situated Learning Epistemology," in Proceedings of the $26^{\text {th }}$ International Conference on Information Systems, D. Avison, D. Galletta, and J. I. DeGross (eds.), Las Vegas, NV, December 11-14, pp. 495-505.

Kerlin, M. J. 1997. "Peter French, Corporate Ethics and the Wizard of Oz," Journal of Business Ethics (16), pp. 1431-1438.

Kimberly, J. R. 1981. "Managerial Innovation," in Handbook of Organizational Design, P. C. Nystrom and W. H. Starbuck, New York: Oxford University Press, pp. 84-104.

Klein, M. 2005. "Responsibility," in The Oxford Companion to Philosophy, T. Honderich (ed.), Oxford, UK: Oxford University Press, p. 816.

Knight, K. E. 1967. “A Descriptive Model of the Intra-Firm Innovation Process," The Journal of Business (40:4), pp. 478-496.

Larsen, T. J. 1998. "Information Systems Innovation: A Framework for Research and Practice," in Information Systems Innovation and Diffusion: Issues and Directions, T. J. Larsen andG. McGuire (eds.), Hershey, PA: Idea Group Publishing, pp. 411-434.

Lauer, Q. 1965. Phenomenology: Its Genesis and Prospect, New York: Harper \& Row.

Leonard, D. 1998. Wellsprings of Knowledge: Building and Sustaining the Sources of Innovation, Boston: Harvard Business School Press.

Lévinas, E. 1998a. Otherwise than Being, or, Beyond Essence, Pittsburgh, PA: Duquesne University Press.

Lévinas, E. 1998b. "Philosophy and the Idea of Infinity," Collected Philosophical Papers (trans. A. Lingis), Pittsburgh, PA: Duquesne University Press, Chapter 4, pp. 47-59.

Lingis, A. (trans.). 1998. "Translators's Introduction," in Collected Philosophical Papers, E. Lévinas, Pittsburgh, PA: Duquesne University Press, pp. vii-xxxi.

McInerney, D. P. A. 2004. Innovative Regions: A Comparative Analysis of the Innovative Activities of Indigenous and Non-indigenous Small and Medium Sized Enterprises (SMEs) in the Shannon and Dublin Regions of Ireland, unpublished Ph.D. thesis, University of Limerick, Ireland.

McNerney, J. 2001. Footbridge Towards the Other: A Philosophical Investigation into the Notion of the Human Person in the Writings of Karol Wojtyla with Special Reference to the Paradigm of the Neighbour, unpublished M.Litt. thesis, Department of Philosophy, University College Dublin, Ireland.

Mohr, L. B. 1969. "Determinants of Innovation in Organizations," The American Political Science Review (63:1), pp. 111-126.

Moran, D. 2000. Introduction to Phenomenology, New York: Routledge.

Nelson, R. R., and Winter, S. G. 1977. "In Search of Useful Theory of Innovation," Research Policy (22:2), pp. 36-76. 
Nonaka, I. 1990. "Redundant, Overlapping Organization: A Japanese Approach to Managing the Innovation Process," California Management Review (32:3), pp. 27-38.

Nystrom, H. 1990. Technological and Market Innovation: Strategies for Product and Company Development, Chichester, UK: Wiley.

Porter, M. 1990. The Competitive Advantage of Nations, New York: Free Press.

Posselt, T. R. 2005. Edith Stein: The Life of a Philosopher and Carmelite, Washington, DC: ICS Publications.

Quinton, A. 2005. "Philosophy," in The Oxford Companion to Philosophy, T. Honderich (ed.), Oxford, UK: Oxford University Press, pp. 702-706.

Rahmanseresht, H. 1988. Towards a Revised Model of Innovation in Organisations, unpublished Ph.D. thesis, University of Hull.

Resca, A. 2006. "Knowledge: Climbing the Learning Ladder to a 'Phenomenological' View," Journal of Information Technology (21:3), pp. 203-210.

Rickards, T. 1985. Stimulating Innovation: A Systems Approach, London: Pinter.

Ring, P. S., and Van de Ven, A. H. 2000. "Formal and Informal Dimensions of Transactions," in Research on the Management of Innovation: The Minnesota Studies, A. H. Van d Ven, H. L. Angle, and M. S. Poole (eds.), New York: Oxford University Press, pp. 637-662.

Roberts, E. B. 1988. "Managing Invention and Innovation," Research-Technology Management, (31), pp. 11-29.

Rogers, E. M. 2003. Diffusion of Innovations ( $5^{\text {th }}$ ed.), New York: Free Press.

Rogers, E. M., and Shoemaker, F. F. 1971. Communication of Innovations: A Cross-Cultural Approach, New York: The Free Press.

Rowe, L. A., and Boise, W. B. 1974. "Organizational Innovation: Current Research and Evolving Concepts,: Public Administration Review (34:4), pp. 284-293.

Schumpeter, J. A. 1934. The Theory of Economic Ddevelopment: An Inquiry into Profits, Capital, Credit, Interest, and the Business Cycle, Boston: Harvard University Press.

Shavinina, L. V. (ed.). 2003. The International Handbook on Innovation, Oxford, UK: Pergamon Press.

Shepard, H. A. 1967. "Innovation-Resisting and Innovation-Producing Organizations," The Journal of Business (40:4), pp. 470-477.

Slappendel, C. 1996. "Perspectives on Innovation in Organizations," Organization Studies (17:1), pp. 107-129.

Sokolowski, R. 2000. Introduction to Phenomenology, New York: Cambridge University Press.

Squires, R. 2005. "Solipsism," in The Oxford Companion to Philosophy, T. Honderich (ed.), Oxford, UK: Oxford University Press, p. 883.

Stein, E. 1989. On the Problem of Empathy (trans. W. Stein) ( $3^{\text {rd }}$ rev. ed.), Washington, DC: ICS Publications.

Susman, G. I., and Evered, R. D. 1978. "An Assessment of the Scientific Merits of Action Research," Administrative Science Quarterly (23:4), pp. 582-603

Swanson, E. B. 1994. "nformation Systems Innovation among Organizations," Management Science (49:9), pp. 1069-1092.

Swanson, E. B., and Ramiller, N. C. 1997. "The Organizing Vision in Information Systems," Organization Science (8:5), pp. 458-474

Swanson, E. B., and Ramiller, N. C. 2004. "Innovating Mindfully with Information Technology," MIS Quarterly (28:4), pp. 553-583

Thompson, V. A. 1965. "Bureaucracy and Innovation," Administrative Science Quarterly (10:1), Special Issue on Professionals in Organizations, pp. 1-20.

Van de Ven, A. H. 1986. "Central Problems in the Management of Innovation," Management Science (32:2), pp. 590-607.

Van de Ven, A. H., Angle, H. L., and Poole, M. S. (eds.). 2000. Research on the Management of Innovation: The Minnesota Studies, New York: Oxford University Press. 
Vanhaverbeke, W., and Cloodt, M. 2006. "Open Innovation in Value Networks," in Open Innovation: Researching a New Paradigm, H. Chesbrough, W. Vanhaverbeke, and J. West (eds.), Oxford, UK: University Press, pp. 258-284.

Vrakking, W. J. 1990. “The Innovative Organization,” Long Range Planning (23:2), pp. 94-102.

Weber, R. 2003. "Editor's Comments: Theoretically Speaking," MIS Quarterly (27:3), pp. iii-xii.

Webster, J., and Watson, R. T. 2002. "Analyzing the Past to Prepare for the Future: Writing a Literature Review," MIS Quarterly (26:2), pp. xiii-xxiii.

Whetten, D. A. 1989. "What Constitutes a Theoretical Contribution?," Academy of Management Review (14:4), pp. 490-495.

Wilson, J. 1966. "Innovation in Organizations: Notes toward a Theory," in Approaches to Organizational Design, J. Thompson (ed.), Pittsburgh, PA: University of Pittsburgh Press, pp. 193-218.

Wolfe, R. A. 1994. "Organizational Innovation: Review, Critique and Suggested Research Directions," Journal of Management Studies (31:3), pp. 405-431.

Yin, R., Heald, K., and Vogel, M. 1977. Tinkering with the System: Technological Innovations in State and Local Services Toronto: Lexington Books.

Zain, M. 1993. A Field Study of Adoption and Implementations of Innovations by Manufacturing Firms in Malaysia, unpublished Ph.D. thesis, Manchester Business School.

Zaltman, G., Duncan, R., and Holbek, J. 1973. Innovations and Organizations, New York: Wiley

\section{About the Authors}

Gabriel J. Costello is a lecturer at the Galway-Mayo Institute of Technology, Ireland. He is currently undertaking a Ph.D. in MIS at the Centre for Innovation and Structural Change (CISC), National University of Ireland, Galway. The research is investigating the area of information systems and innovation with an emphasis on its challenges for practice, theory, and philosophy. Prior to this he worked for 20 years in the telecommunications industry. Gabriel can be contacted at gabrielj.costello@gmit.ie.

Brian Donnellan is a lecturer and researcher in the Cairnes Postgraduate School of Business and Public Policy in the National University of Ireland, Galway (NUIG). His research interests lie primarily in the area of innovation systems, a broad area that encompasses knowledge management, new product development, and technology management. Prior to joining the NUIG faculty, he spent 20 years working in the ICT industry. Dr. Donnellan is currently associated with the Centre for Innovation and Structural Change (CISC), an interdisciplinary research center in NUIG investigating the innovation processes and policies that are fundamental to the development of a knowledge-based economy. Dr. Donnellan is responsible for the interorganizational systems research stream in CISC. The goals of this research stream are to investigate the salient operational features of inter-firm networks and collaborative relationships, including those with a regional dimension, to determine the extent to which interorganizational systems provide a platform for value-added partnerships, and to devise feedback loops between research and teaching so that course materials and delivery are informed by best practice in the area. He can be contacted at brian.donnellan@nuigalway.ie. 


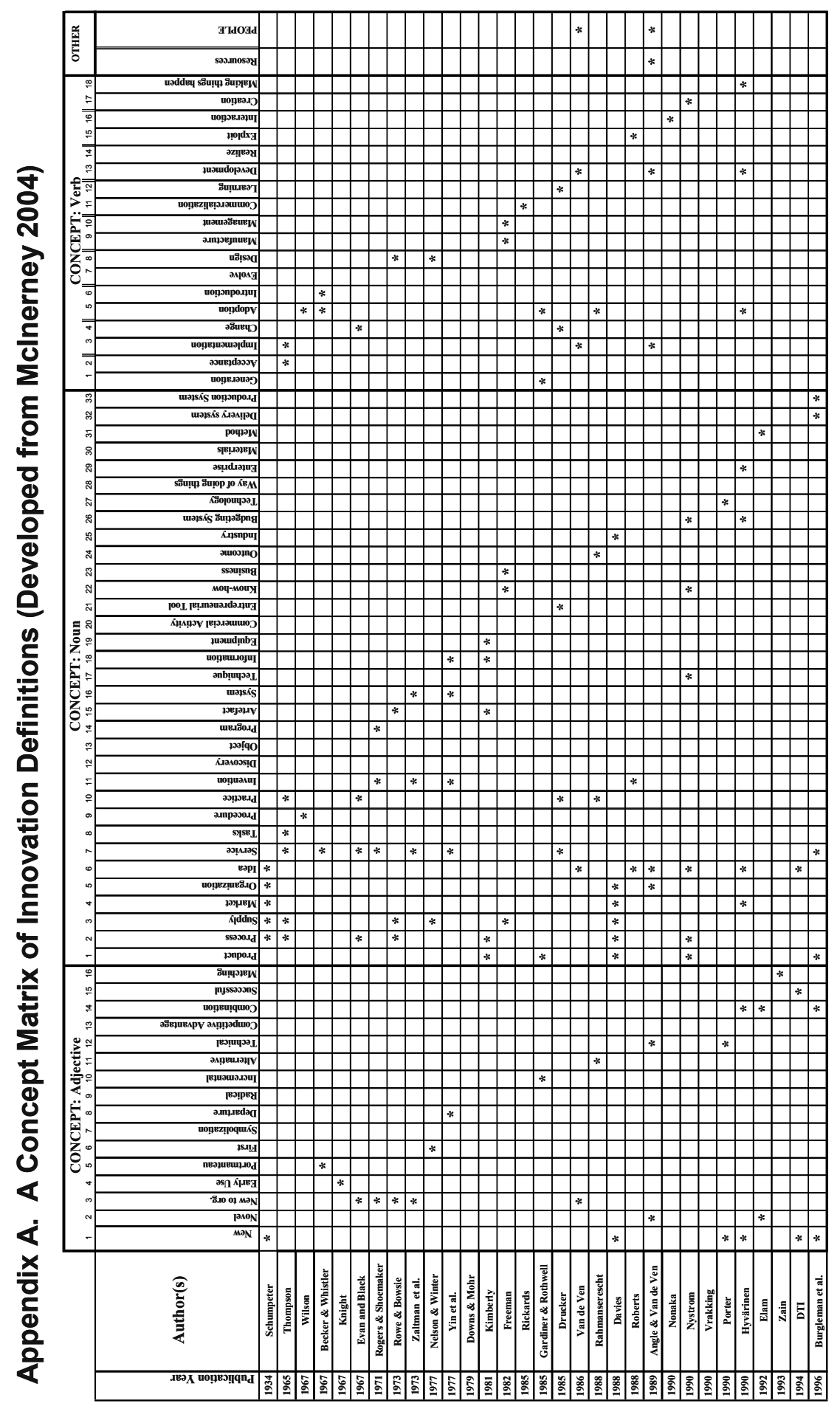




\section{Appendix B. Definitions of Innovation}

Definitions taken mainly from the work of (McInerney 2004) which was developed from antecedent studies by Rahmanseresht (1988) and Zain (1993).

\begin{tabular}{|c|c|}
\hline Innovation Definition & Author \\
\hline $\begin{array}{l}\text { New products, new methods of production, new sources of supply, the } \\
\text { exploitation of new markets and new ways to organize business }\end{array}$ & Schumpeter (1934) \\
\hline $\begin{array}{l}\text { Generation, acceptance, and implementation of new ideas, processes, } \\
\text { products and services. }\end{array}$ & Thompson (1965) \\
\hline $\begin{array}{l}\text { An innovation or more precisely a major innovation is a fundamental } \\
\text { change in a "significant number" of tasks. }\end{array}$ & Wilson (1966) \\
\hline $\begin{array}{l}\text { The first or early use of an idea by one of a set of organizations with } \\
\text { similar goals. }\end{array}$ & $\begin{array}{l}\text { Becker \& Whistler } \\
(1967)\end{array}$ \\
\hline $\begin{array}{l}\text { An innovation is the adoption of a change which is new to an } \\
\text { organization and to the relevant environment. }\end{array}$ & Knight (1967) \\
\hline $\begin{array}{l}\text { The implementation of new procedures or ideas s whether a product of } \\
\text { invention or discovery, will be referred to as "innovation." }\end{array}$ & $\begin{array}{l}\text { Evan \& Black } \\
(1967)\end{array}$ \\
\hline $\begin{array}{l}\text { When an organization learns to something it did not do before and it } \\
\text { proceeds to do it in a sustained way a process of innovation has } \\
\text { occurred }\end{array}$ & Shepard (1967) \\
\hline $\begin{array}{l}\text { The successful introduction into an applied situation of means or cods } \\
\text { that are new to the situation }\end{array}$ & Mohr (1969) \\
\hline $\begin{array}{l}\text { An innovation is an idea, practice, or object perceived as new by an } \\
\text { individual. It matters little, as far as human behaviour is concerned } \\
\text { whether or not an idea is objectively new as measured by the lapse. of } \\
\text { time since its first uses or discovery....if the idea seems new and } \\
\text { different to the individual, it is innovation }\end{array}$ & $\begin{array}{l}\text { Rogers \& } \\
\text { Shoemaker } \\
(1971)\end{array}$ \\
\hline $\begin{array}{l}\text { The successful utilization of processes, programs, or products which } \\
\text { arc new to an organization and which are introduced as a result of } \\
\text { decisions within that organization. }\end{array}$ & $\begin{array}{l}\text { Rowe \& Boise } \\
(1974)\end{array}$ \\
\hline $\begin{array}{l}\text { New idea, practice, or material artefact perceived to be new by the } \\
\text { relevant adopting unit. }\end{array}$ & $\begin{array}{l}\text { Zaltman et al. } \\
(1973)\end{array}$ \\
\hline $\begin{array}{l}\text { Innovation is defined as the earliness or extent of use by a given } \\
\text { organization of a given new idea, where new means only now to the } \\
\text { adopting agent, and not necessarily to the world in general. }\end{array}$ & $\begin{array}{l}\text { Downs \& Mohr } \\
(1976)\end{array}$ \\
\hline $\begin{array}{l}\text { A portmanteau to cover the wide range of variegated processes by } \\
\text { which man's technologies evolve over time. }\end{array}$ & $\begin{array}{l}\text { Nelson \& Winter } \\
(1977)\end{array}$ \\
\hline $\begin{array}{l}\text { Innovation includes any discrete idea, practice or material artefact that } \\
\text { is introduced for the first time... and is seemingly discontinuous with } \\
\text { past practice. The term technological innovation moreover, refers to } \\
\text { those innovations that consist of (1) an artefact or material (2) a } \\
\text { computer system or (3) an analytic idea or practice that lends itself to } \\
\text { quantitative symbolization. }\end{array}$ & $\begin{array}{l}\text { Yin et al. } \\
(1977)\end{array}$ \\
\hline
\end{tabular}




\begin{tabular}{|c|c|}
\hline Innovation Definition & Author \\
\hline $\begin{array}{l}\text { A managerial innovation is any program product or technique which } \\
\text { represents a significant departure from the state of the art of manage- } \\
\text { ment at the time it first appears and which affects the nature, location, } \\
\text { quality or quantity of information that is available in the decision } \\
\text { making progress }\end{array}$ & Kimberly (1981) \\
\hline $\begin{array}{l}\text { Industrial innovation includes the technical design, manufacturing, } \\
\text { management, and commercial activities invoked in the marketing of a } \\
\text { new (or improved) process or equipment. }\end{array}$ & Freeman (1982) \\
\hline Commercialization of invention. & Rickards (1985) \\
\hline $\begin{array}{l}\text { Innovation does not necessarily imply the commercialization of only a } \\
\text { major advance in the technological state of the art (radical innovation) } \\
\text { but it includes also the utilization of even small-scale changes in } \\
\text { technological know-how (incremental innovation). }\end{array}$ & $\begin{array}{l}\text { Gardiner \& } \\
\text { Rothwell (1985) }\end{array}$ \\
\hline $\begin{array}{l}\text { Innovation is the specific tool of entrepreneurs, the means by which } \\
\text { they exploit change as an opportunity for a different business or } \\
\text { service. It is capable of being presented as a discipline, capable of } \\
\text { being learned, capable of being practiced. }\end{array}$ & Drucker (1985) \\
\hline $\begin{array}{l}\text { The process of development and implementation of new ideas by } \\
\text { people who over time engage in transactions with others within an } \\
\text { institutional context. }\end{array}$ & Van de Ven (1986) \\
\hline $\begin{array}{l}\text { The process whereby an adoption unit chooses a significant alternative } \\
\text { that is perceived as superior to and/or different from some current } \\
\text { practice or outcome and attempts to realize it so that a deficiency in the } \\
\text { practice or outcome can be corrected or so that either/or both can be } \\
\text { improved. }\end{array}$ & $\begin{array}{l}\text { Rahmanseresht } \\
(1988)\end{array}$ \\
\hline $\begin{array}{l}\text { Innovation includes the opening up of markets, the conquest of new } \\
\text { sources of supply of materials, new forms of organization of an } \\
\text { industry, including the creation or breaking up of monopoly positions } \\
\text { as well as process and product innovations. }\end{array}$ & Davies (1988) \\
\hline $\begin{array}{l}\text { The generation of an idea while innovation incorporates both invention } \\
\text { and exploitation. }\end{array}$ & Roberts (1988) \\
\hline $\begin{array}{l}\text { A purposeful, concentrated effort to develop and implement a novel } \\
\text { idea that is of substantial technical, organizational and market uncer- } \\
\text { tainty that entails a collective effort of considerable duration and that } \\
\text { requires greater resources than are held by the people undertaking the } \\
\text { effort. }\end{array}$ & $\begin{array}{l}\text { Angle \& Van de } \\
\text { Van (1989) }\end{array}$ \\
\hline $\begin{array}{l}\text { Innovation is a product of the interaction between necessity and } \\
\text { chance, order or disorder, continuity and discontinuity. }\end{array}$ & Nonaka (1990) \\
\hline $\begin{array}{l}\text { Any renewal designed and realized, that strengthens organization's } \\
\text { competitiveness. }\end{array}$ & Vrakking (1990) \\
\hline $\begin{array}{l}\text { Companies achieve competitive advantage through acts of innovation. } \\
\text { They approach innovation in its broadest sense, including both new } \\
\text { technologies and new ways of doing things. }\end{array}$ & Porter (1990) \\
\hline $\begin{array}{l}\text { The creation of the future- the process of bringing new ideas } \\
\text { (products, processes, know-how, budgeting systems, management } \\
\text { techniques, etc.) into use. }\end{array}$ & Nystrom (1990) \\
\hline
\end{tabular}




\begin{tabular}{|l|l|}
\hline \multicolumn{1}{|c|}{ Innovation Definition } & \multicolumn{1}{c|}{ Author } \\
\hline $\begin{array}{l}\text { Innovativeness is a combination of technological, enterprise and market } \\
\text { and other environmental dimensions by which means that a small and } \\
\text { medium sized industrial enterprise develops and adopts new ideas, also } \\
\text { other than technical ones, for industrial use or for markets earlier than } \\
\text { other corresponding enterprises. }\end{array}$ & Hyvarinen (1990) \\
\hline $\begin{array}{l}\text { The combining of materials in a novel fashion to produce other things } \\
\text { or the same things by a different method. }\end{array}$ & Elam (1993) \\
\hline $\begin{array}{l}\text { The process of matching organizational and environmental means and } \\
\text { needs. }\end{array}$ & Zain (1993) \\
\hline Successful exploitation of new ideas. & DTI (1994) \\
\hline $\begin{array}{l}\text { The "combined activities leading to new marketable products and } \\
\text { services and/or new production and delivery systems." }\end{array}$ & $\begin{array}{l}\text { Burgelman et al. } \\
\text { (1996) }\end{array}$ \\
\hline
\end{tabular}

